\title{
713 歩行面の横摇れと歩行リズムの同期現象
}

Synchronization of walking rhythm with lateral vibration of walking surface

$\begin{array}{cllll}\text { O正 } & \text { 宇津野秀夫（京大） } & \text { 井辻 } & \text { 隆志 (トヨタ自動車) } \\ \text { 正 } & \text { 松久 } & \text { 寛 } & \text { (京大) }\end{array}$

Hideo UTSUNO, Kyoto University, Yoshida Honmachi, Sakyo-ku, Kyoto

Takashi ITSUI, Toyota Motor Corporation, Hiroshi MATSUHISA, Kyoto University, Park Jeong Gyu

\begin{abstract}
The lateral vibration of pedestrian bridge was induced by human walking in London. It was caused by the synchronization of human walking rhythm with lateral vibration of the bridge, but the mechanism of that synchronization has not been cleared yet. In this paper, the lateral vibration of pendulum with human walking was investigated by using neural oscillators model. Firstly, the neural oscillators themselves were testified numerically whether it could be applied to human walking. Then, human walking model on the pendulum was formulated, combining neural oscillators and the pendulum vibration. Experiments were carried out to investigate the synchronization phenomenon in various conditions and they were compared with the calculated results. The presented neural oscillators might simulate the synchronization of human walking on the vibrating bridge.
\end{abstract}

Key Words: Neural oscillators, pendulum, synchronization, human walk, vibration

\section{A 1.はじめに}

ロンドンのミレニアムブリッジで橋の横摇れに人の歩行 リズムが同調し, 横摇れがー層増幅される問題が発生した. 本研究では，身体運動のリズム生成と深い関係にある神経 振動子に着目し，歩行に関与る人と外部環境との相互作用 を解析と実験の両面から検討する.

\section{A 2. 神経振動子モテルと台上歩行実験}

歩行現象を表現する神経振動子の数学モデルに歩行面 の横摇れに相当する正弦波を外部入力として与え, 出力の 周波数を計算した. 図 A1 に示すように外部入力のない状態 の歩行周波数 $0.7 \mathrm{~Hz}$ に対して，その周波数の $\mathrm{n}$ 倍付近では 出力周波数が入力周波数に比例する同調現象が出現した.

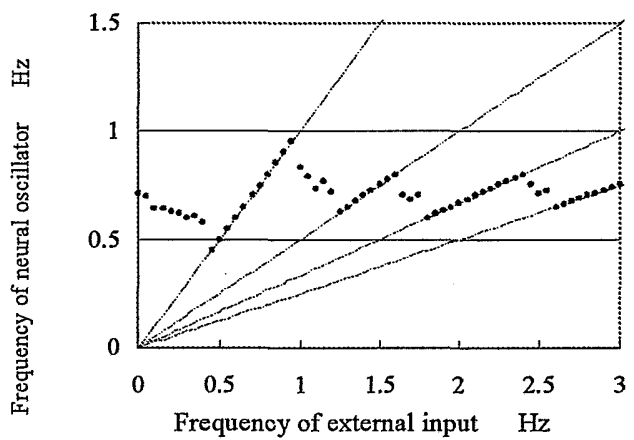

Fig. Al Synchronization of neural oscillator with external input.

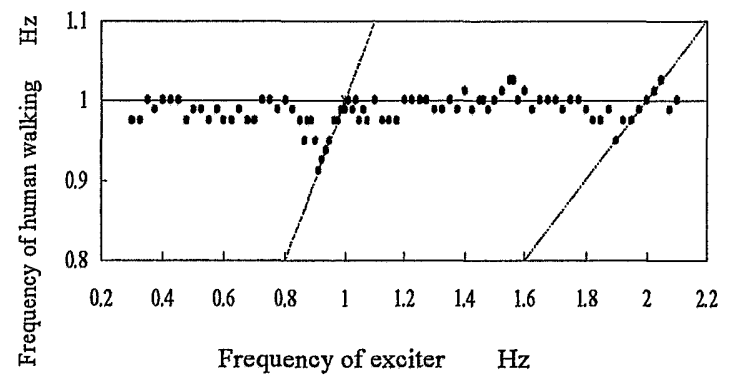

Fig. A2 Synchronization of human walking experiments.
そこで横摇れする加振台上で人間による足踏み試験を行い， 加振周波数と足踏み周波数の関係を図 A2に整理した. 実験 においても神経振動子モデルと同じ同調現象が確認された。

\section{A 3．自由振動する台上の歩行モデルと実験}

図 A3 に示すように左右に自由振動する吊下げ台上で足 踏みするモデルを考える. 足踏み時の人体の動きを高速度 カメラで撮影し，人体の運動モデルを作成した. 台単体の 固有振動数を台の腔の長さ Lを調節して変化させ，台と人 からなる系の応答が最大となる周波数を測定した. 図 A4 に示すように，自由振動する台上でも人の歩行リズムは台 の固有振動数に同調する結果が得られた，また数値計算と 実験とはよく対応する結果が得られた。
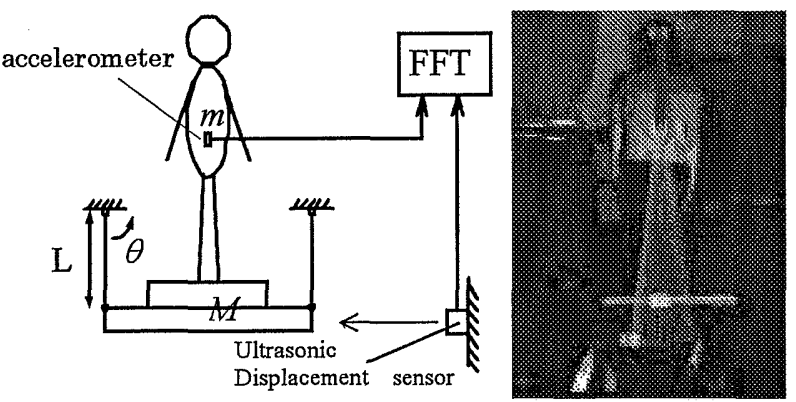

Fig. A3 Pendulum with human walking.

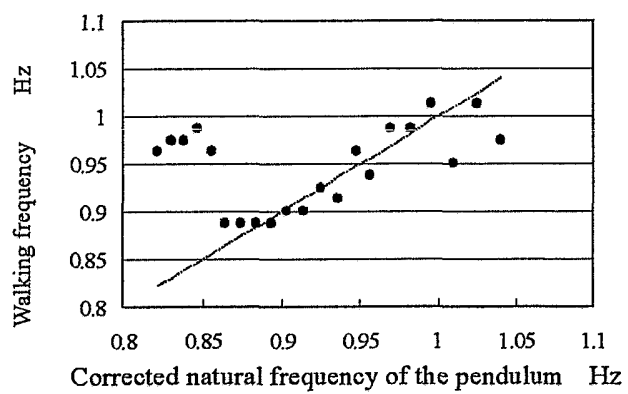

Fig. A4 Walking rhythm and natural frequency of the pendulum with human. 
1.はじめに

ロンドンのミレニアムブリッジは，開通直後に人の 歩行が原因で橋が大きく横摇れし，一時的に閉鎖され た.Fujinoら "は，この現象が橋の横摇れの周期に人 が歩調を合わせて歩いてしまう「引き込み現象」で， 同じ歩調で歩く人が増すことでさらに橋の横摇れが増 大した現象であることを報告している。一方多賀 ${ }^{2.31}$ は人の歩行を神経振動子を用いた数学モデルで表現で きることを報告している，そこで本研究 ${ }^{4)} ゙$ は，人と 外部環境との相互作用の視点から，人の歩行りズムを 生成する神経振動子と歩行面の摇れとの関係を解析と 実験の両面から検討する.

まず初めに，歩行現象を表現する神経振動子の数学 モデルに外部入力として歩行面の横摇れを与え，数值 計算を行う. 次に神経振動子が生成する歩行りズムと 外部環境の関係を確認するため，横摇れする加振台上 で足踏み実験を行い，歩行りズムを測定する. 続けて 自由振動する台上で人が歩行する場合を考え，数値シ ミュレーションと実験で歩行リズムを検討する. 以上 の一連の研究を通して，振動面上の人の歩行問題に関 して, 人と外部環境との相互作用を表す数理モデルを 構筑する。

\section{2. 神経振動子}

\section{1 神経振動子の数学モデル}

脊椎動物の沓髄には，歩行などのリズム運動をつか さどるセントラルパターンジェネレーター(CPG と略 す)と呼ばれる神経回路網が存在することが知られて いる。この CPG を構成する最小単位が神経振動子であ る. 神経振動子は自律的に振動を生成するが，外部か ら周期的な入力があると神経振動子は固有のリズムを 変化させて, 外部の振動数と一致させる引き込み現象 を生じる、本研究では，松岡ら ${ }^{5)} か ゙$ 提案した下記の一
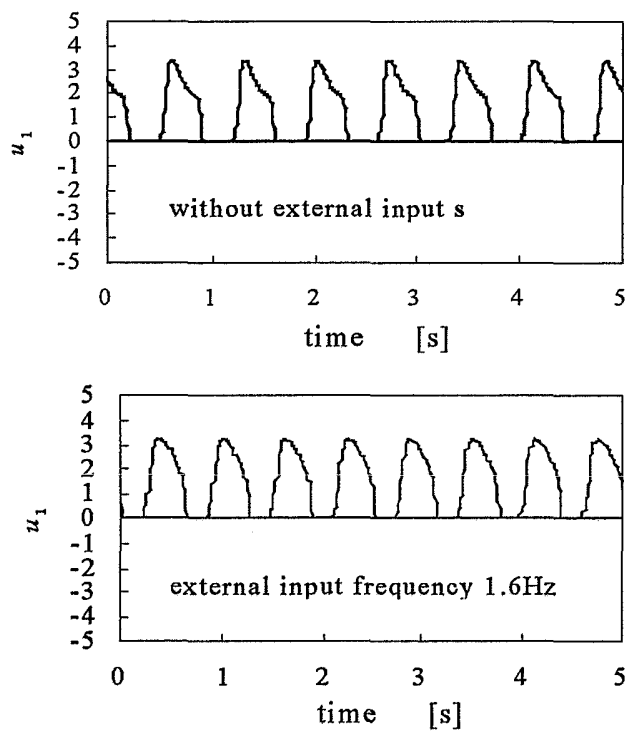

対の神経素子からなる神経振動子を歩行の数学モデル として用いる。

$$
\begin{aligned}
& \tau_{1} \dot{u}_{1}=-u_{1}-\alpha f\left(v_{1}\right)+\beta f\left(u_{2}\right)+u_{0}+s \\
& \tau_{1}^{\prime} \dot{v}_{1}=-v_{1}+f\left(u_{1}\right) \\
& \tau_{2} \dot{u}_{2}=-u_{2}-\alpha f\left(v_{2}\right)+\beta f\left(u_{1}\right)+u_{0}-s \\
& \tau_{2}^{\prime} \dot{v}_{2}=-v_{2}+f\left(u_{2}\right) \\
& f(u)=\max (0, u)
\end{aligned}
$$

ここで， $u_{1,2}$ は神経素子の内部状態， $v_{1,2}$ は神経素 子の疲労状態， $\tau_{1,2}$ は内部状態の時定数， $\tau_{1,2}^{\prime}$ は疲労 状態の時定数， $\alpha$ は影響係数， $\beta$ は神経素子同士の結 合強度， $u_{0}$ は定常入力, $s$ は外部入力である.

外部入力 $s$ は神経振動子に対する外部からの刺激で あり，定常入カ $u_{0}$ は $\mathrm{CPG}$ 全体の活動を変化させるパラ メータである。神経振動子はこの方程式に従い，外部 からの刺激 $s$ に応じてリズム生成を行う。神経振動子 の出カは $u_{1}, u_{2}$ で，一方が関節における屈曲筋，他方 が伸展筋の動きに対応する。一般的な值として $\tau_{1}=\tau_{2}=0.031 ， \tau_{1}^{\prime}=\tau_{2}^{\prime}=0.377, \alpha=2.5, \quad \beta=-2.0$ ， $u_{0}=6.0$ を用い，外部入力がない場合と振動数 1.1，1.6, 1. $7 \mathrm{~Hz}$ の正弦波を入カした場合の神経素子 $u_{1}$ の出力時 間波形を図1に示す.

\section{2 神経振動子の引き込み現象}

歩行は右足と左足の一歩ずつで 1 周期と考えるため， 歩数の半分の值を基準に考える必要がある. 図 1 に示 した神経素子 $u_{1}$ の出力は, 右足と左足の屈曲筋の運動 が交互に繰返される状態を意味するため，歩行の振動 数は神経振動子の出力振動数の $1 / 2$ 倍に換算して考え た。すなわち外部入カがない場合，神経振動子は約 0.7 $7 \mathrm{~Hz}$ の固有なリズムを生成する。振動数 $1.1 \mathrm{~Hz}$ と 1.7Hzの正弦波を外部入カとして与えた場合，神経振
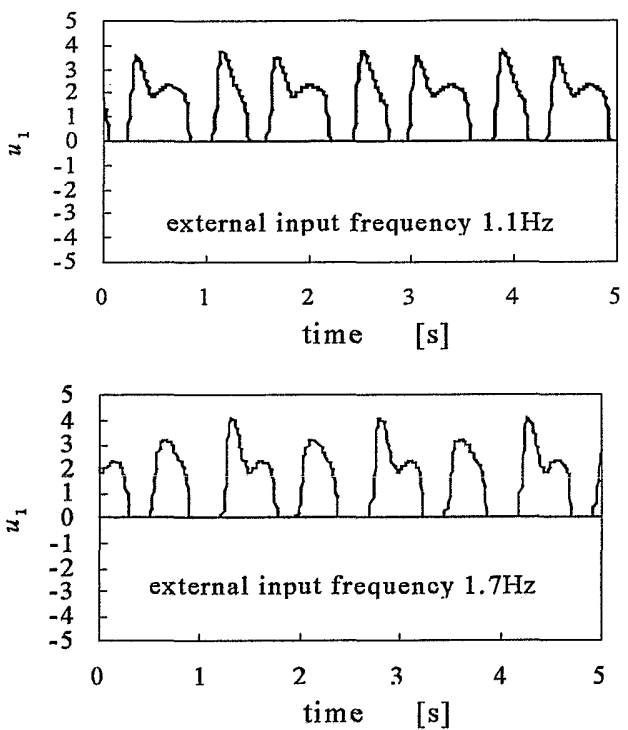

Fig. 1 Response of neural oscillator for various sinusoidal external input. 
動子は外部入力に引き込まれることはないが，生成さ れるリズムは不規則な波形を示す. 外部入力の振動数 が 1. $6 \mathrm{~Hz}$ の場合は出力の時間波形はその半分の $0.8 \mathrm{~Hz}$ となる.図 2 は, 同じく神経振動子に正弦波を入カし た場合であるが，入力振動数と出力振動数の関係を整 理して示したものである. 図中に示した直線の切片は 0 で，傾きは左から順に 1，1/2，1/3，1/4 となってい る.入力振動数が神経振動子の固有リズムの n 倍 $(n$ : 自然数)に近いとき，出力振動数は入力振動数の $1 / n$ 倍の值に引き込まれる. 入力振動数が固有のリズムの $\mathrm{n}$ 倍から離れているときは，入力振動数に影響される こと無く出力振動数は固有のリズムを維持している.

\section{3.振動台上での人間の歩行実眏}

図了に本実験の模式図とその写真を示す.被験者は， 一定振幅 $20 \mathrm{~mm}$ で種々の正弦波で加振される加振台上 で足踏みを行う.最初の 10 秒間は自分の歩行リズムの

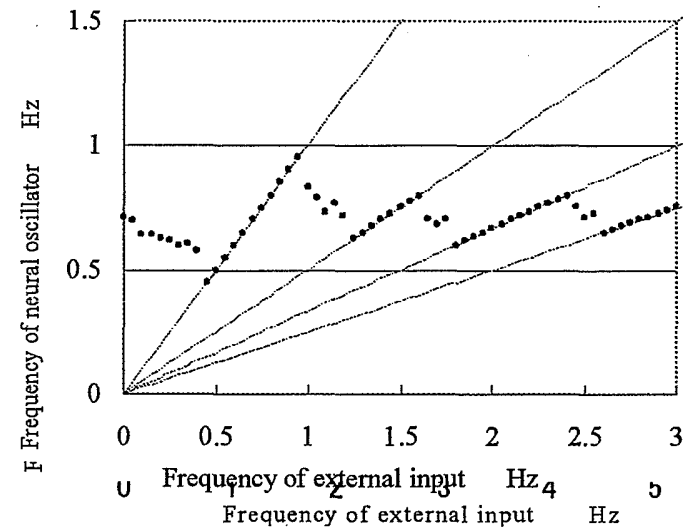

Fig. 2 Synchronization of neural oscillator with external input.
メトロノーム音に合わせて足踏みし，メトロノーム音 を消した後は自分の歩きやすいリズムで 80 秒間足踏 みを続ける。被験者の腰に装着したセンサで後半 40 秒間の加速度を検出し，フーリエ変換して足踏みの振 動数を求めた。

図 4 に実験結果を示す，横軸が加振振動数，縱軸が 足踏みの振動数である. 被験者に固有な足踏みの振動 数は $0.975 \mathrm{~Hz}$ である. 図中の直線の傾きは，左から順 に，1/1，1/2であり，その切片は0.である. 両直線上 には複数の測定点が明確に存在し，またそれ以外の領 域においては，足踏みの振動数はほほ固有のリズムに 等しい值を示している。従って人間の歩行リズムは， 神経振動子の生成するリズムと同様に引き込み現象を 起こしていると言える。

図5には3人の被験者の測定結果を示す。一定振幅 $20 \mathrm{~mm}$ で歩行の固有リズムに近い周波数で加振してい
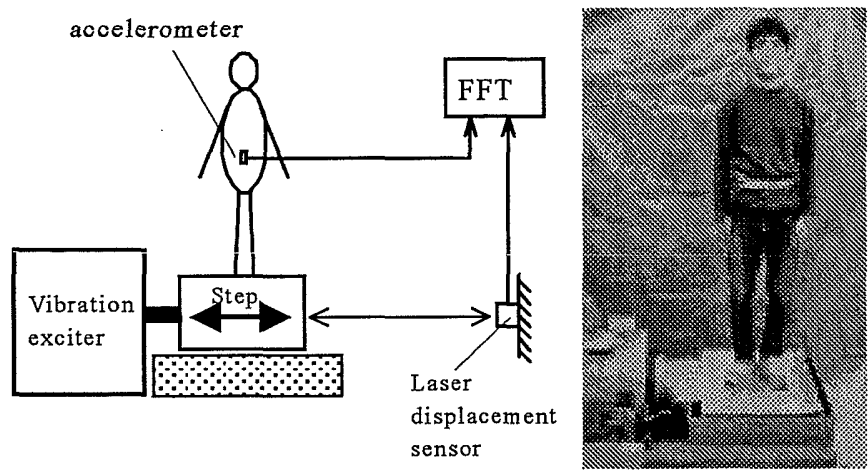

Fig. 3 Experiments for human walking on the vibration exciter.

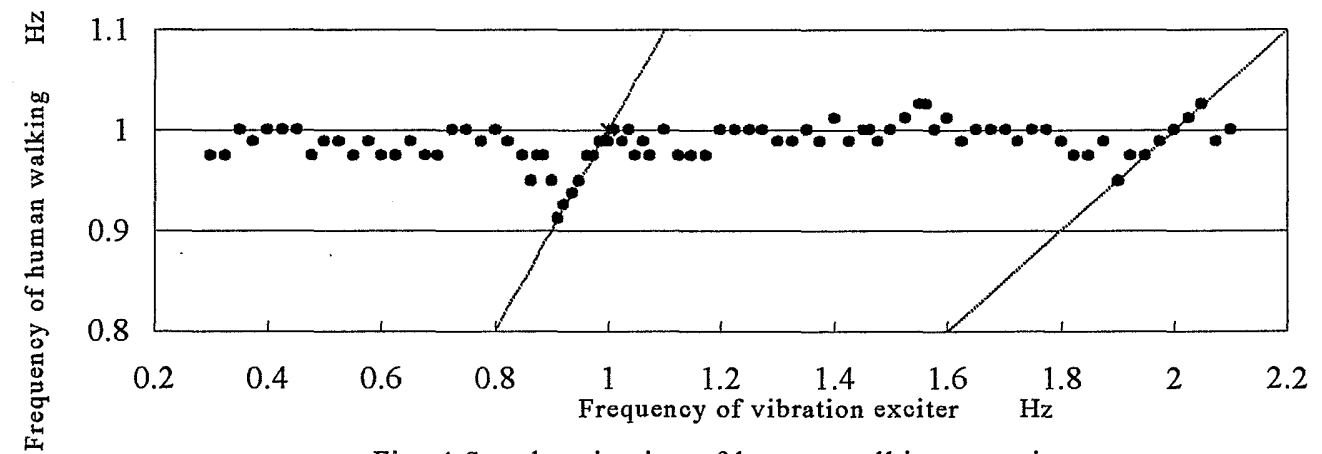

Fig. 4 Synchronization of human walking experiments
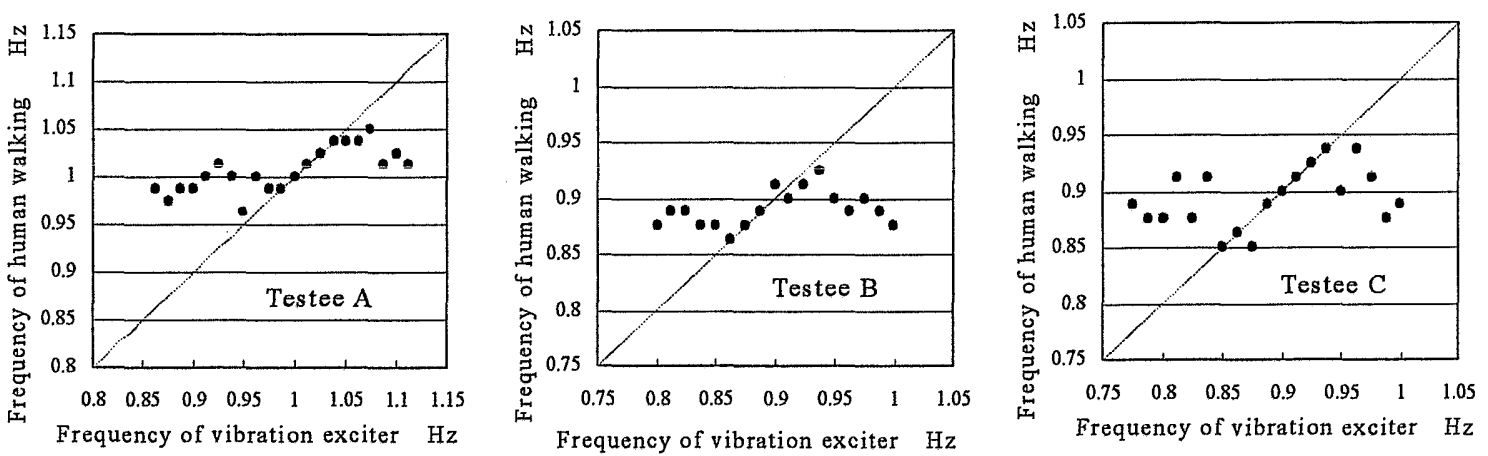

Fig. 5 Synchronized areas of walking experiments for three testees. 


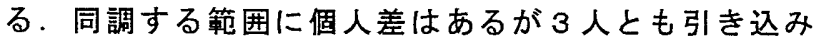
現象を確認できる。

\section{4.自由振動する台上での歩行リズム}

\section{1 歩行リズムの計算}

図 6 に示すように質量 $m$ の人を載せた質量 $M$ の台 を考える. 台は長さ $L$ の 2 本の腕で吊下げられており， 左右に動くことができる。ここでは台が動いても人は 台とともに左右に動き，相対位置関係が変化しないと 仮定して次の運動方程式を考える.

$$
(M+m) L \ddot{\theta}+(M+m) g \theta=F_{0} \sin \omega t
$$

人間の歩行リズムは式(1)-(5)に示した神経振動子 モデルを用い，台の運動方程式と連立させる，人間か ら台への入力は人間の足踏みによる台への横荷重であ り，その時間波形は角振動数 $\omega$ の正弦波と仮定した。 また振幅 $F_{0}$ は Jaeger らの研究 ${ }^{6-8)}$ を参考に，質量 $m$ $\mathrm{kg}$ の人間が足踏みをする際，一歩ごとに $0.4 \mathrm{~m} \mathrm{~N} \cdot \mathrm{s}$ の 力積が体の側方に発生すると仮定した。 また台から人
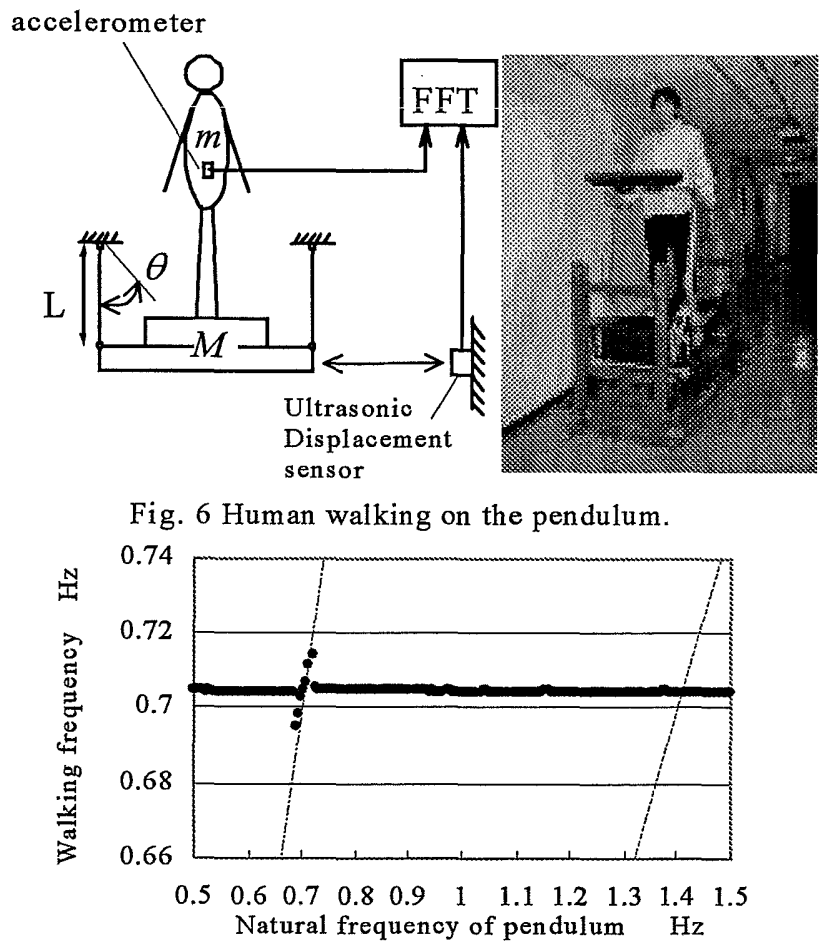

(a) Human walking frequency

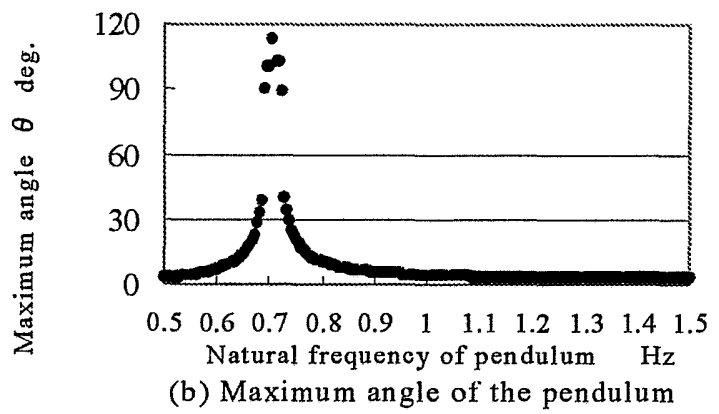

Fig. 7 Calculated response of the pendulum.
間への入力は式 (1)中の外部入力 $s$ であり，この値に は台の加速度に係数 $\gamma$ を乗じた値とした.なお，人間 の体重を $60 \mathrm{~kg}$ ，台の質量を $75 \mathrm{~kg}$ ，係数の値を 15 とし て計算を行った。

図7に計算結果を示す.図7(a)の横軸は台の固有振 動数で，縱軸は足踏みの振動数を表す。図 $7(\mathrm{~b})$ の縦軸 は台の最大角変位である.また同図中の直線の傾きは， 左から順に，1/1，1/2，であり，その切片は0である.

前節で述へたように強制加振される台上では，足踏 みのリズムは複数の加振周波数に引き込まれた。しか しながら本計算結果においては，傾き $1 / 1$ の直線上に のみ引き込み現象が現れている，すなわち， $n=1$ の引 き込み現象しか生じていない，これは歩行リズムが 0.7Hz を基本としており，加振振動数にはその高次成 分も存在するが，台の共振を考慮しても歩行リズム以 外の振動数では台の振動振幅が小さく，引き込み現象 を生じなかったためと解釈できる。このことは図 7(b) において，引き込み現象が生じている振動数帯域での み台の角変位が増大していることからも理解できる.

\section{2 歩行リズムの湘定実験}

腕の長さ $L$ を变えることで台の固有振動数を变 化させ，各固有振動数に対して足踏みのリズムを測 定する。振動台と同様に，被験者は振子型の台上で 一定時間足踏みを行う。足踏みの振動数は被験者の 腰に装着した加速度センサの信号をフーリエ变換し て求め，台の変位は超音波変位計で測定する。

測定結果を図8に示す. 図8(a)は横軸が台の固有 振動数，縦軸が足踏みの振動数であり，図8(b) は縱

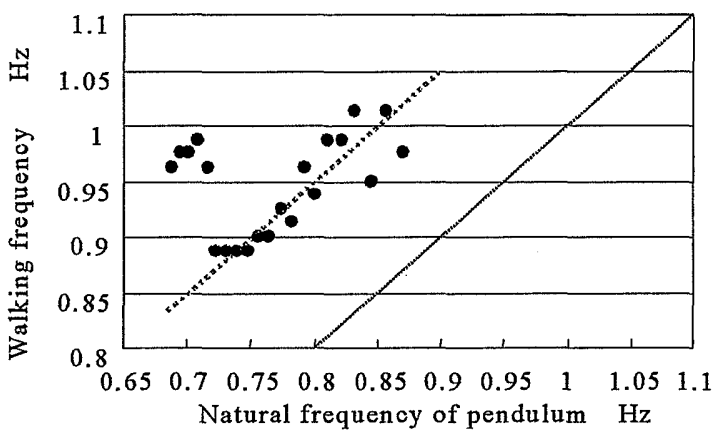

(a) Human walking frequency

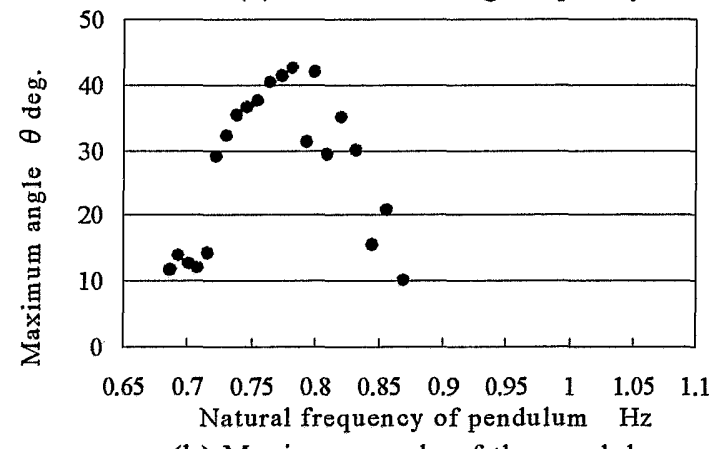

(b) Maximum angle of the pendulum

Fig. 8 Measured response of pendulum. 
軸が台の最大角变位である。図8(a)に傾き1, 切片 0 の直線を実線で示す．計算では足踏みの振動数が引き 込まれてこの直線上にプロットされたが，実験では歩 行振動数は台の固有振動数より大きな值を示した。た だし足踏みの振動数は破線で示すように台の固有振動 数に対して切片 0 ではないが，傾きが 1 に近い直線上 にあり，図8(b)に示す台の最大角变位は計算結果と同 様の形状を示している.このため台に人が乗ることで， 系の固有振動数が変化したと考え，図 9 に示すように 高速度カメラで足踏みの様子を撮影し， 2 次元動画解 析ソフトを用いて身体の動きを解析した，人間が横摇 れする台上で足踏みすると，上半身は直立し，下半身 が腰を中心に振り子状に運動していることが分かる。

図 9 に示すように人間の質量を腰部に集中させ，この 質量の左右方向の運動は拘束し，上下方向にのみ運動 するモデルを考える. 微小振幅を仮定して次式の運動 方程式を得る。

$$
\begin{aligned}
\left\{M+m\left(1-\frac{L}{a}\right)^{2} \theta^{2}\right\} \ddot{\theta} & +m\left(1-\frac{L}{a}\right)^{2} \dot{\theta}^{2} \theta \\
& +g\left(\frac{M+m}{L}-\frac{m}{a}\right) \theta=0
\end{aligned}
$$

ここで $M, m, L, a$ はそれぞれ台の質量，人間 の質量，台の腕の長さ，腰から台までの長さであり， $\theta$ は台の角変位である. 微小量のべき粪項を無視すると 台の固有振動数は次式で与えられる。

$$
f=\frac{1}{2 \pi} \sqrt{\frac{g}{L}\left\{1+\frac{m}{M}\left(1-\frac{L}{a}\right)\right\}}=f_{0} \sqrt{1+\frac{m}{M}\left(1-\frac{L}{a}\right)}
$$

ここで $f_{0}$ は台のみの固有振動数である．仮に $M=75 \mathrm{~kg}, m=60 \mathrm{~kg}, a=1.0 \mathrm{~m}$ とすると式 (7)の固有振動 数は $f=1.18 f_{0}$ となり図 $8(\mathrm{a})$ に示した測定值に近い值 となる.

そこで台の腕の長さを変化させ，台上の被験者には 台の振幅が増大するように意識して足踏みを行わせて 振動数を測定する実験を行った. 図 10 は横軸に台のみ の固有振動数をとり，縦軸に足踏み時の固有振動数を 示す.式 (7) で計算された微小振幅時の固有振動数を実 線で示している。計算值と実験值はほぼー致している が，この実験結果の場合には切片0で傾き 1.2 の1次 関数でも近似可能であった.

簡便化するため，台のみの固有振動数に係数 1.2 を 乗じた值を足踏み時の固有振動数と考え，図 8 を修正 して図 11 に示す。同図 (a)に傾き1，切片０の直線を 実線で示すが，この直線上に足踏みの振動数が分布す る領域 $(0.85 \mathrm{~Hz} \sim 1.0 \mathrm{~Hz})$ が存在することから，足踏みの 振動数と人間の乗った台の固有振動数との間に引き込 み現象を生じていることが分かる。なお図11(b)に示 したように，台の最大角変位もこの振動数域において 増大しており，数値計算の傾向と一致している.
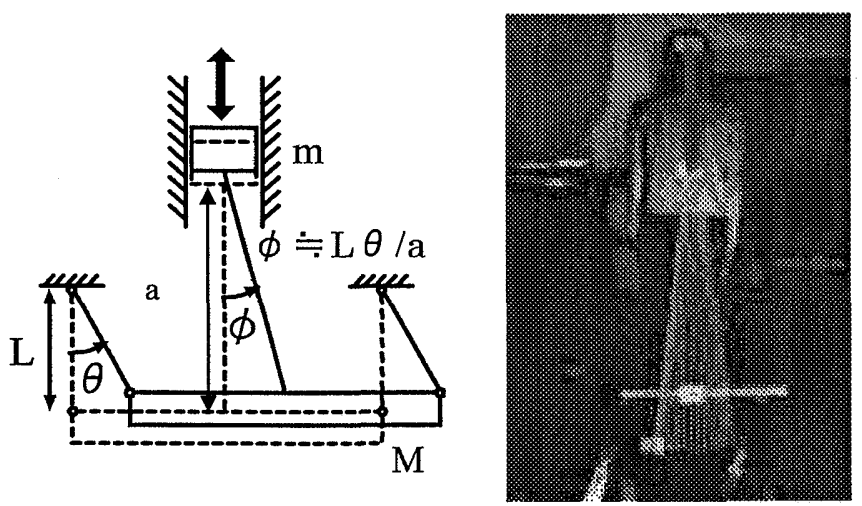

Fig. 9 Schematic diagram of pendulum with human walking.

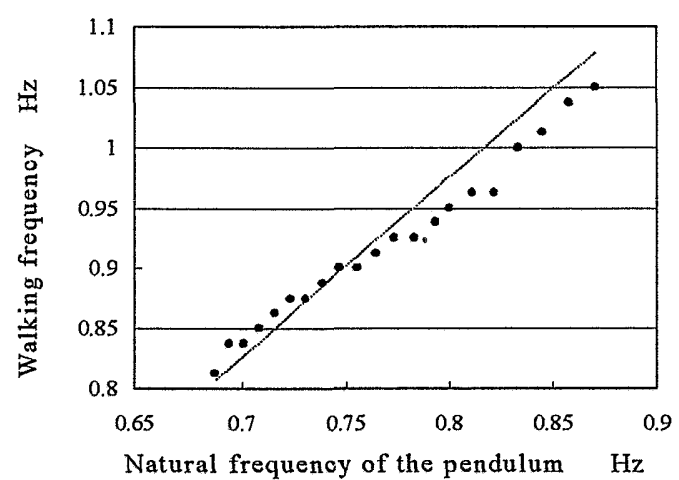

Fig. 10 Walking frequency measured for the model.

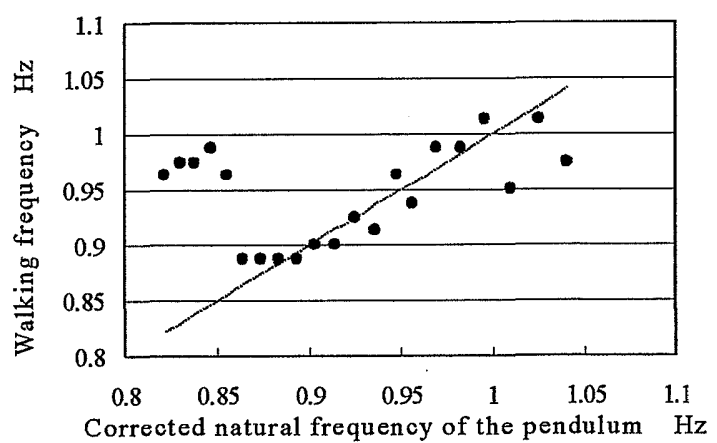

(a) Human walking frequency.

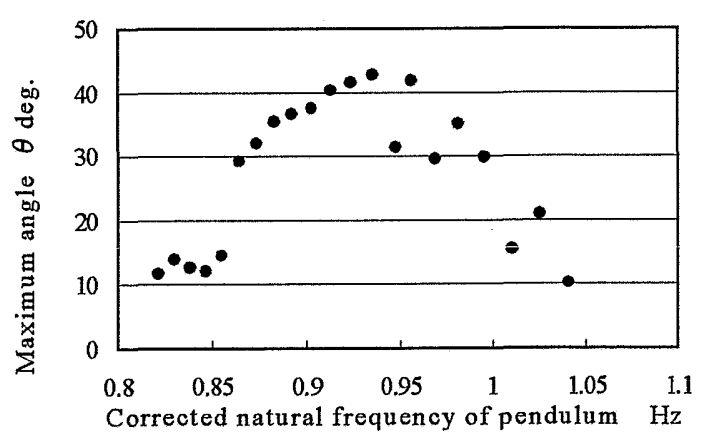

(b) Maximum angle of the pendulum.

Fig. 11 Measured response of the pendulum. 


\section{4. 結 喜}

身体運動のリズム生成を司る神経振動子に着目して， 歩行に関する人と外部環境との相互作用を解析と実験 の両面から検討し, 以下の結論を得た。

1) 入力振動数が，神経振動子の固有の振動数 の $n(n$ : 自然数) 倍に近いとき, 出力振動数は入力振動 数の影響を受けて引き込み現象を起こす。

2）強制加振された台上で足踏み実験を行うと，人の歩 行リズムは，加振周波数に引き込まれた。この実験 結果は神経振動子シミュレーションと同様な傾向を 示した。

3）自由振動する台上を歩行する場合，台の固有振動数 でのみ引き込み現象を起こした。

4）人が乗った場合の台の固有振動数は, 入の動きによ って変化する。

\section{参考文献}

(1) Y.Fujino, et al. , Synchronization of human walking observed during lateral vibration of a congested pedestrian bridge, Earthquake eng. and struct dyn, 22, 741-758 (1993)

（2）多賀厳太郎，身体運動の生成と発達のデザイン原理， シミュレーション，第 15 巻第 4 号, pp. 239-246, 1996.

（3）多賀笽太郎，視覚誘導歩行における䐘神経系・身体・ 環境の動的カップリング，システム/制御/情報，Vol. 46, No. 1，pp. 9-14, 2002.

（4）松久寞，歩道橋の横摇れによる歩行リズムの同期現象， D\&D2003

(5) K. Matsuoka, Mechanisms of Frequency and Pattern Control in the Neural Rhytm Generators , Biol.Cybern., 56, pp. 345-353, 1987.

（6）上村德秀，連続体補助構造物を用いた橋の上下振動の 制振, 2000 .

(7) Colum D. Mackinnon and David A. Winter, CONTROL OF WHOLE BODY BALANCE IN THE FRONTAL PLANE DURING HUMAN WALKING, J.Biomechanics, Vol. 26, No. 6 , pp. 633-644, 1993.

(8) R. J. Jaeger and P. Vanitchavan, GROUND REAGTION FORCES DURING TERMINATION OF HUMAN 